\title{
Suppression of guanylyl cyclase ( $\beta 1$ subunit) expression impairs neurite outgrowth and synapse maturation in cultured cerebellar granule cells
}

\author{
ME López-Jiménez ${ }^{1,2}$, D Bartolomé-Martín ${ }^{1,2}$, J Sánchez-Prieto ${ }^{1}$ and M Torres ${ }^{\star, 1}$
}

The increased expression of different soluble guanylyl cyclase (sGC) subunits during development is consistent with these proteins participating in the formation and establishment of interneuronal contacts. Functional sGC is generated by the dimerization of an $\alpha$-subunit ( $(\mathrm{SGC} \alpha 1 / 2)$ with the $\beta 1$-subunit ( $\mathrm{SGC} \beta 1$ ), and both depletion of the $\mathrm{SGC} \beta 1$ subunit and inhibiting sGC activity impair neurite outgrowth. Similarly, impairing sGC activity diminishes the amount of growth-associated protein (GAP-43) and synapsin I, two proteins that participate in axon elongation and synaptogenesis, suggesting a role for SGC in these processes. Indeed, fewer synapses form when sGC is inhibited, as witnessed by FM1-43 imaging and synapsin I immunostaining, and the majority of synapses that do form remain functionally immature. These findings highlight the importance of sGC in the regulation of neurite outgrowth and synapse formation, and in the functional maturation of cerebellar granule cells in vitro. Cell Death and Differentiation (2009) 16, 1266-1278; doi:10.1038/cdd.2009.57; published online 22 May 2009

During neuronal development, cGMP signaling is important to modulate growth cone activity in a variety of cell types. ${ }^{1-3}$ Indeed, intracellular cGMP synthesis is linked to and mediates the neurogenic effects of different factors, including that of nerve growth factor (NGF). ${ }^{4}$ The expression of the different guanylyl cyclase subunits (sGC), the main physiological receptor for nitric oxide (NO), augments throughout development in different areas of the rat brain and in in vitro models of neuronal maturation. ${ }^{5-7}$ Accordingly, these proteins may be important for the formation and growth of neuronal processes, as well as for the establishment of intercellular contacts and the refinement of functional neuronal connections within the peripheral and central nervous system. ${ }^{1,8,9}$ There are two known isoforms of sGC, the ubiquitous $\alpha_{1} \beta_{1}$ and $\alpha_{2} \beta_{1}$, which has a more limited distribution. ${ }^{10}$ This latter isoform interacts with synaptic scaffolding proteins through its PDZ domains, suggesting that this enzyme is accumulated in synapses ${ }^{11,12}$ and that it is responsible for cGMP synthesis in this cellular compartment. $^{13}$

GAP-43 is an integral membrane protein associated with the cytoplasmic surface of axonal growth cones in developing neurons, and it is generally considered an intrinsic determinant of neurite outgrowth and plasticity. ${ }^{14,15}$ In addition, GAP-43 also plays important roles in synaptogenesis as well as in regulating the cytoskeletal organization of the nerve ending. ${ }^{16}$ Indeed, neurite outgrowth and axonal pathfinding are affected when GAP-43 expression is altered, both during development and in cultured cells. Likewise, synapsins are also thought to participate in the processes of axon elongation and synapse formation during development, and the expression of synapsin I correlates well with synapse maturation. ${ }^{17}$ Synapsins are exclusively associated with small synaptic vesicles and they are virtually excluded from other tissues or neuroendocrine cells. ${ }^{18}$ Indeed, synapsin I is probably the most specific marker of synapses in the central and peripheral nervous system, and it regulates the availability of vesicles for exocytosis as well as cytoskeletal dynamics within nerve terminals. ${ }^{19}$ Furthermore, synapsins are required to establish a reserve pool of vesicles that can be efficiently recruited to the active zone, thereby maintaining the adequate release of neurotransmitters under conditions of very active synaptic transmission. 20

The expression of both the nNOS and SGC (subunits- $\beta 1$ and $-\alpha 2$ ) augments during the development of rat cerebellar granule cells in vitro, as well as in the cerebellum. ${ }^{5,21}$ Moreover, NMDA receptor stimulation, which is essential for the survival and differentiation of developing cerebellar granule cells, ${ }^{22}$ upregulates the expression of these proteins in vitro. ${ }^{5,23}$ Together, these data reflect the importance of such proteins for the correct development of cerebellar granule cells. Given that the $\beta_{1}$ subunit of $\mathrm{SGC}$ is the obligatory dimerization partner for both $\alpha$-subunits to render a functional enzyme, we analyzed the effects of knocking down sGC $\beta 1$ in granule cells. The results we obtained led us to conclude that

\footnotetext{
${ }^{1}$ Departamento de Bioquímica, Facultad de Veterinaria, Universidad Complutense, Madrid, Spain

*Corresponding author: M Torres, Departamento de Bioquímica, Facultad de Veterinaria, Universidad Complutense de Madrid, Madrid, Spain.

Tel: + 34913943 891; Fax: + 34913943 909; E-mail: mitorres@vet.ucm.es

${ }^{2}$ These authors contributed equally to this work.

Keywords: guanylyl cyclase; neuronal development; neurite outgrowth; synaptogenesis; FM1-43; functional synapse maturation

Abbreviations: AUF, A + U-rich element binding factor; 8-Br-cGMP, 8-bromo-guanosine $3^{\prime} 5^{\prime}$-cyclic monophosphate; cGK, cGMP-dependent protein kinase; cGMP, guanosine $3^{\prime} 5^{\prime}$-cyclic monophosphate; DEA-NONOate, (2-(N,N-diethylamino)-diazenolate-2-oxide); DIV, days in vitro; FITC, fluorescein isothiocyanate; LDH, lactate dehydrogenase; MO- $\beta 1$, morpholino antisense oligonucleotide of the soluble guanylyl cyclase $\beta 1$ subunit gene; NMDA, $N$-methyl-D-aspartic; nNOS, neuronal nitric oxide synthase; NO, nitric oxide; ODQ, $1 H$-[1,2,4]oxadiazolo[4,3-a]quinoxalin-1-one; sGC, soluble guanylyl cyclase; sGC $\beta 1$, beta soluble guanylyl cyclase; siRNA, small interfering RNA

Received 25.7.08; revised 21.4.09; accepted 24.4.09; Edited by L Greene; published online 22.5.09
} 
sGC activity plays a prominent role in regulating neurite outgrowth and synapse formation, as well as in the functional maturation of synapses. Indeed, sGC activity appears to regulate the expression of different synaptic proteins that are critical for axonal growth, synapse formation and maturation.

\section{Results}

Depletion of endogenous SGC $\beta 1$ by RNA interference impairs neurite outgrowth in cerebellar granule cells. Nucleofection led to the efficient transfection of cerebellar granule cells with siRNA duplexes against the sGC $\beta 1$ subunit. Following transfection, the cells were plated on glass coverslips, and after $48 \mathrm{~h}$ in culture, the cells were fixed and stained for $\mathrm{sGC} \beta 1$. Although both the soma and neuronal processes were specifically labeled in control nucleofected cells (CE), cells transfected with sGC $\beta 1$ siRNA were only weakly labeled, indicating that the expression of this protein was efficiently knocked down (Figure 1a). The reduction in both $\mathrm{sGC} \beta 1 \mathrm{mRNA}$ and protein observed after $24 \mathrm{~h}$ was maintained at 48 and $72 \mathrm{~h}$, although the levels were completely restored to normal 7 days after transfection (Figure 1b). Cell viability was not affected by sGC $\beta 1$ siRNA transfection at any time point analyzed, as measured by the lactate dehydrogenase (LDH) activity in the cells or with an MTT (MTS)-based assay.

Cerebellar granule cells begin to emit neurites immediately after plating (at this stage we refer to dendrites or axons as neurites) and as they mature, their number and length increased giving rise to a dense network of fibers connected through many synaptic contacts. Fixed and crystal violetstained cells were analyzed for neurite emission, neurite number and neurite length. In control conditions, most cells emitted neurites in the first $22 \mathrm{~h}$ after plating (1860 of 2000; Figure $2 a$ and $b$ ) and indeed, the majority of these cells emitted multiple processes (more than two; Figure 2c). Only a small proportion of these cells remained round and did not emit neurites (142 of 2000). Transfection of granule cells with sGC $\beta 1$ siRNA significantly increased the proportion of cells that retained a round shape after $22 \mathrm{~h}$ and that did not emit neurites (404 out of 1049 cells, $P<0.01$ ) and as a consequence, fewer cells developed neurites (653 of 1049 cells, $P<0.05)$. Indeed, most transfected cells had only one or two neurites (341 of 1049) and in contrast to the control population $(82.5 \pm 1.5 \%)$, only $29 \pm 11.5 \%$ of cells developed multiple neurites (304 of 1049, $P<0.01$; Figure 2c). The length of the neurites was not affected by sGC $\beta 1$ knockdown ( $P>0.05$; Figure 2d), although the level of GAP-43 (a marker of axonal growth) diminished (Figure $2 e$ ) and it was only $55.3 \pm 7 \%$ of that in the control nucleofected cells $48 \mathrm{~h}$ after transfection $(94 \pm 6 \%)$.

\section{Morpholino antisense oligonucleotide transfection causes longer lasting knockdown of $s G C \beta 1$ and it leads to neurite retraction and cell death. As siRNA produced a transitory knockdown of $\mathrm{sGC} \beta 1$, we tested the feasibility of adopting a morpholino antisense approach to produce a more long-term depletion of $\mathrm{sGC} \beta 1$ (MO- $\beta 1$ ). Morpholino antisense oligonucleotides very efficiently}

a
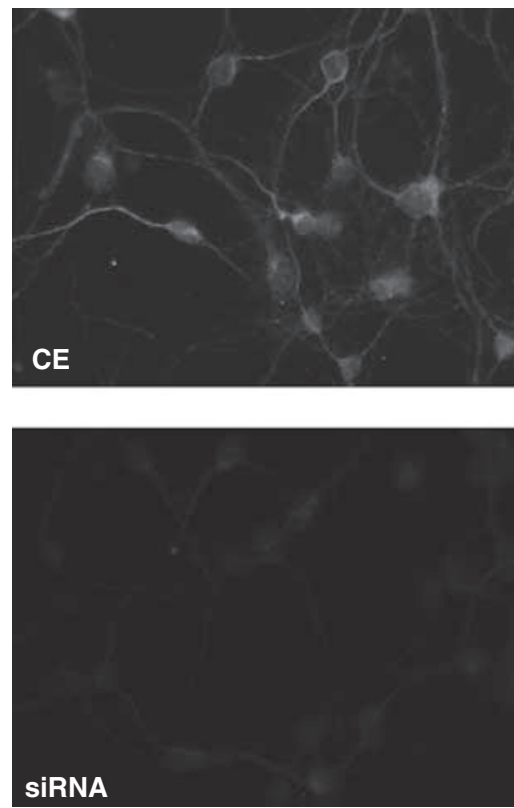

b

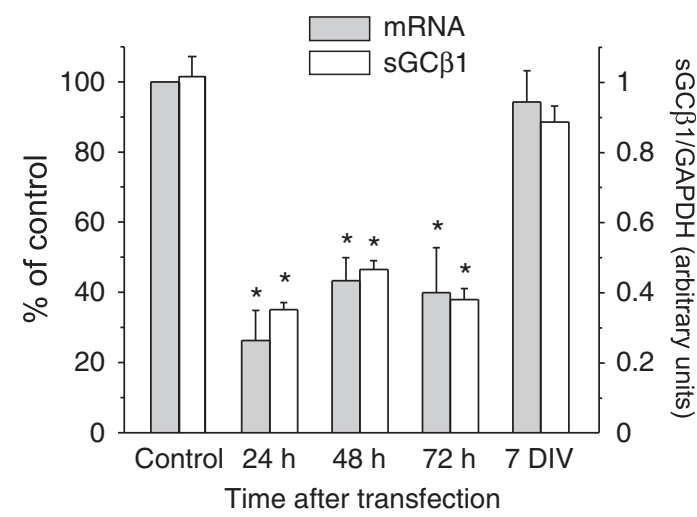

C

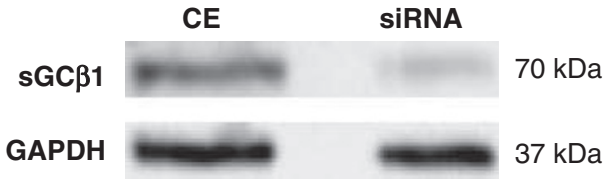

Figure 1 Transfection of cerebellar granule cells with small interfering RNA (siRNA) duplexes against sGC $\beta 1$ by nucleofection effectively knocks down sGC $\beta 1$ expression. (a) Immunocytochemistry with anti-guanylyl cyclase $\beta 1$ (ER-19; 1 : 400; Sigma) showing the efficiency of sGC $\beta 1$ knockdown of the siRNAs $48 \mathrm{~h}$ after transfection (CE: control nuclofected cells with nonsilencing siRNA; siRNA: cells nucleofected with siRNA sGC $\beta 1$ ). Bars $20 \mu \mathrm{m}$. (b) Evolution of the sGC $\beta 1 \mathrm{mRNA}$ and protein levels after transfection. The mRNA levels were normalized to $18 \mathrm{~S}$ rRNA and the protein levels were normalized to GAPDH. The data represent the mean \pm S.E.M. of at least three different experiments performed on different cultures $\left({ }^{*} P<0.01\right.$ compared with the respective control, one-way ANOVA followed by Bonferroni test). (c) Western blots probed with anti-guanylyl cyclase $\beta 1$ (ER-19, $1 \mu \mathrm{g} / \mathrm{ml})$ and an anti-GAPDH mouse monoclonal lgG (1 $\mu \mathrm{g} / \mathrm{ml}$; Ambion) showing the decrease in sGC $\beta 148 \mathrm{~h}$ after transfection 


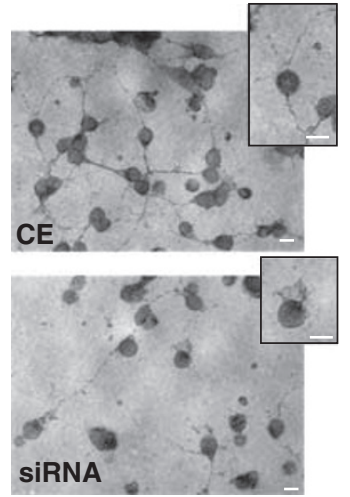

b

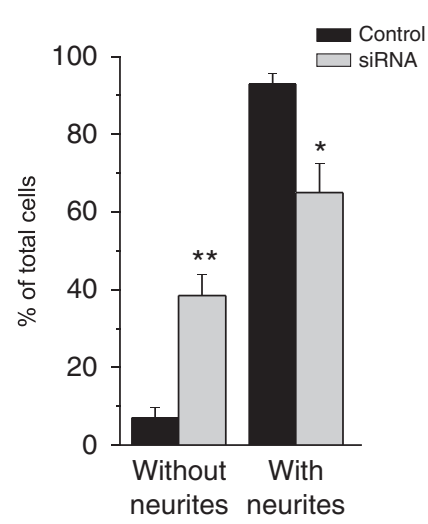

C

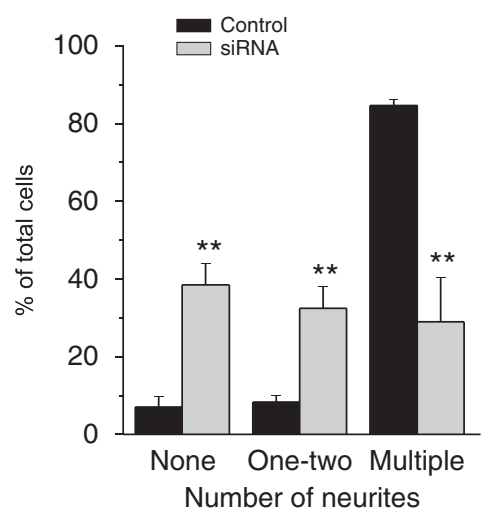

d

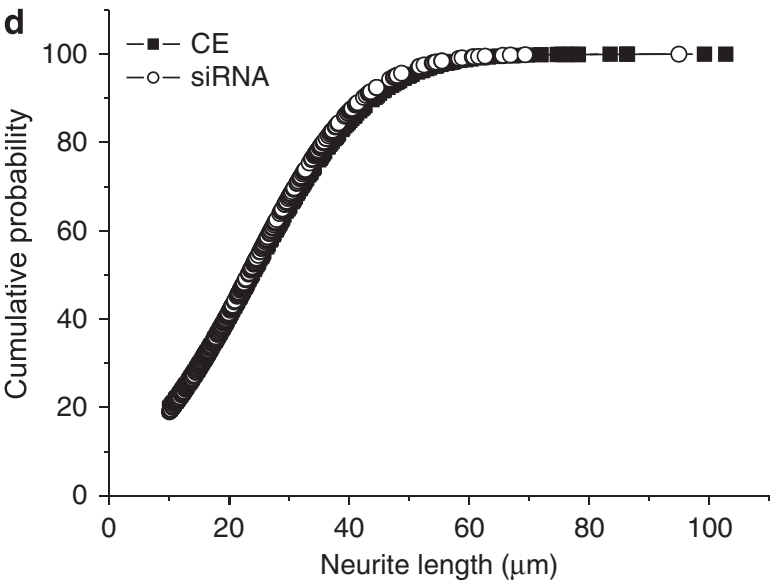

e

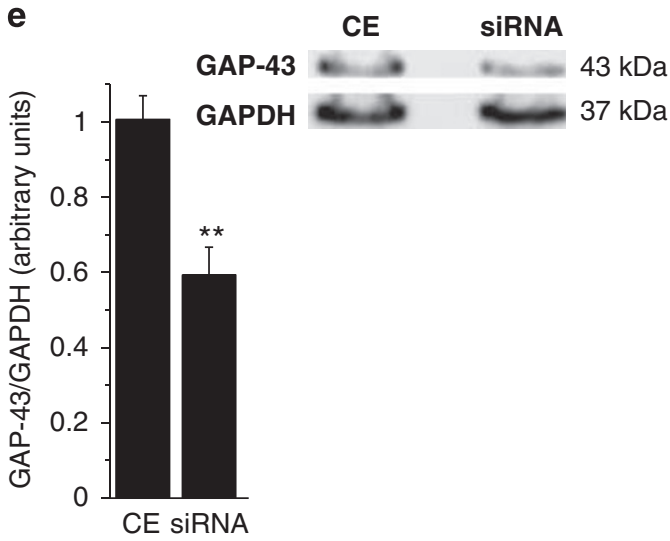

Figure 2 The knockdown of SGC $\beta 1$ impairs neurite outgrowth. (a) Images of crystal violet-stained cerebellar granule cells (control nucleofected or transfected with siRNA sGC $\beta 1$ ) grown in vitro for $22 \mathrm{~h}$. Higher magnification shows the most abundant cells in each condition with multiple neurites (control) or round cells (siRNA transfected cells). Bars $10 \mu \mathrm{m}$. (b) Summary of the number of cells (control or transfected with siRNA sGC $\beta 1$ ) with or without neurites after $22 \mathrm{~h}$ in culture, expressed as a percentage of the total number of cells (control: 2000 cells and siRNA transfected: 1049 cells). (c) Summary of the number of cells (control or transfected with siRNA sGC $\beta 1$ ) that emitted a different number of neurites after $22 \mathrm{~h}$ in culture, expressed as percentage of the total number of cells (control: 2000 cells and siRNA transfected: 1049 cells). Data (b, c) represent the mean \pm S.E.M. of three different cultures (significant differences from control values are indicated: ${ }^{*} P<0.01,{ }^{*} P<0.05, t$-test). (d) Cumulative probability plots of neurite length from control (214 neurites) and siRNA-transfected cells (108 neurites). The two plots are not significant different $(P>0.05 ;$ Mann-Whitney $U$-test; $P>0.05$; Kolmogorov-Smirnov test). (e) Quantification of GAP-43 expression after $48 \mathrm{~h}$ normalized to the GAPDH content in control or transfected cells. Data represent the mean \pm S.E.M. of four different experiments performed on different cultures $\left({ }^{* *} P<0.01\right.$ compared with the respective controls, one-way ANOVA). Right panel: representative western blot showing the downregulation of GAP-43 $48 \mathrm{~h}$ after transfection with siRNA $\mathrm{SGC} \beta 1$. The membrane was probed with an anti-GAP-43 mouse monoclonal IgG $1 \mu \mathrm{g} / \mathrm{ml}$ (Zymed Laboratories) and an anti-GAPDH mouse monoclonal antibody lgG $1 \mu \mathrm{g} / \mathrm{ml}$

inhibit protein expression by specifically blocking mRNA translation. ${ }^{24}$ Indeed, $48 \mathrm{~h}$ after transfection of granule cells with MO- $\beta 1$ the level of SGC $\beta 1$ had dropped to $49.5 \pm 9.2 \%$ $(P<0.05$; Figure $3 \mathrm{a}$ and $\mathrm{b})$ that of control cells and this reduction persisted for 5 days after transfection $(56.5 \pm 6.5 \%$, $P<0.01$ ), without affecting the corresponding mRNA levels. Although the viability of MO- $\beta 1$-transfected cells was not statistically different from that of control cells after $48 \mathrm{~h}$, 5 days after transfection the cultures of the cells transfected with MO- $\beta 1$ were less dense than those of control cells or of the cells transfected with the inverse antisense (used as a negative control for morpholino transfection; Figure $3 \mathrm{c}$ ). The LDH activity in the cells that received the MO- $\beta 1$ decreased to $65 \pm 3.2 \%$ the control values (Figure $3 b$; $P<0.01$ ), whereas this depletion in SGC $\beta 1$ protein and loss of viability was not observed in cells transfected with the inverse antisense. As expected, the levels of GAP-43 also decreased to $43.5 \pm 6.4 \%(P<0.05)$ that of control cells $48 \mathrm{~h}$ after transfection, reaching $29 \pm 3.5 \% 5$ days after transfection (Figure $3 \mathrm{a}$ and $\mathrm{b} ; P<0.01$ ).

Inhibition of SGC with ODQ mimics the early and late effects caused by the knockdown of the sGC $\beta 1$ subunit. We wondered whether inhibiting SGC activity might produce the same effect as the partial silencing of its expression. Hence, cells were incubated for $22 \mathrm{~h}$ with the specific SGC inhibitor, ODQ, and then fixed and stained with crystal violet to count and measure neurites. Neurite emission was impaired in cells exposed to ODQ (Figure 4a) and although only $12.2 \pm 1.3 \%$ of cells remained without neurites in control conditions, this value increased threefold on exposure to ODQ (50 $\mu \mathrm{M}$ : $36.14 \pm 3.34 \% ; P<0.001)$. Thus, 
a

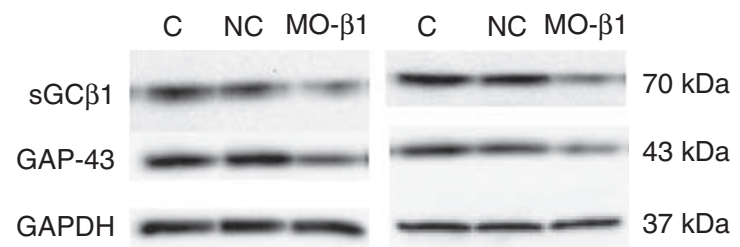

b
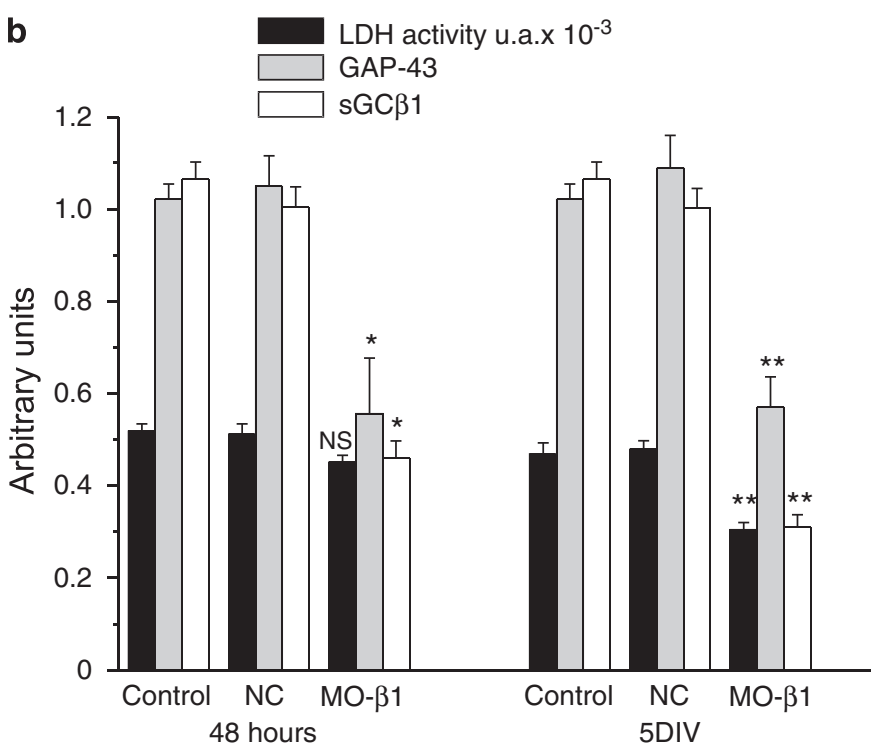
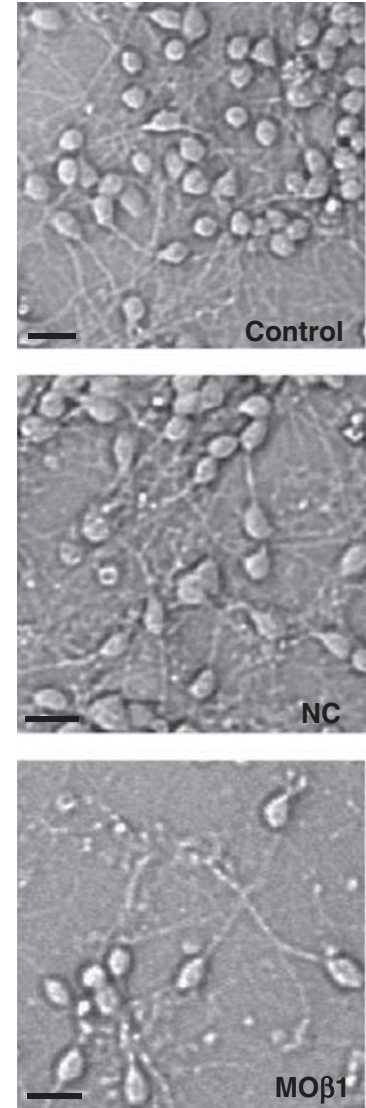

Figure 3 Transfection of granule cells with morpholino antisense oligonucleotides against the sGC subunit $\beta 1$ gene (MO- $\beta 1$ ). (a) Western blots for sGC $\beta 1$, GAP-43 and GAPDH from cell extracts $48 \mathrm{~h}$ (left panel) or 5 days (right panel) after transfection. C: control, NC: negative control and MO- $\beta 1$ : morpholino antisense oligonucleotide. (b) Quantification of SGC $\beta 1$ and GAP-43 normalized to GAPDH expression, and LDH activity in the cells expressed in arbitrary fluorescence units at $48 \mathrm{~h}$ and $5 \mathrm{DIV}$ (days in vitro). Fluorescence units of LDH activity were interpolated in a calibration plot (number of cells versus LDH activity). At $48 \mathrm{~h}$ : control, $72738 \pm 3841$ cells; $\mathrm{NC}, 71879 \pm 4664 \mathrm{cells}$; MO, $63511 \pm 3703$ cells, and at 5 DIV: control, $65981 \pm 4938$ cells; NC, $67352 \pm 4252$ cells; MO, $43484 \pm 3703$ cells. The membranes were probed with anti-guanylyl cyclase $\beta 1(1 \mu \mathrm{g} / \mathrm{ml}$, ER-19) anti-GAP-43 mouse monoclonal lgG $(1 \mu \mathrm{g} / \mathrm{ml})$, and anti-GAPDH mouse monoclonal lgG $(1 \mu \mathrm{g} / \mathrm{ml})$. The data represent the mean \pm S.E.M. of three different cultures (Significant difference from control values is indicated: ${ }^{\star *} P<0.01,{ }^{*} P<0.05$; one-way ANOVA followed by Bonferroni test). (c) Phase contrast image of granule cells maintained for 5 days in culture: NC, negative control, MO- $\beta 1$ cells transfected with the morpholino antisense oligonucleotide. Bar: $20 \mu \mathrm{m}$

ODQ inhibited neurite emission in a similar manner to that produced by the knockdown of $\mathrm{sGC} \beta 1$ protein expression in cells. Cell viability remained unaffected by the presence of ODQ for $22 \mathrm{~h}$ as measured by the LDH content or the reduction in MTS. However, when the number of neurites emitted was counted, there was a clear decrease in the number of cells with multiple neurites in the presence of ODQ (Figure $4 \mathrm{a}$ ). Although $71 \pm 5 \%$ of control cells had emitted multiple neurites after $22 \mathrm{~h}$, only $30 \pm 3.3 \%$ of cells exposed to ODQ $(50 \mu \mathrm{M})$ developed multiple neurites $(P<0.001)$. Nevertheless, the mean length of the neurites was not affected by ODQ (Figure $4 \mathrm{~b}$ ). In addition, cells exposed to ODQ accumulated less GAP-43 than control cells (60 $\pm 6.7 \%, P<0.001$; Figure 4c), and although 8-Br-cGMP $(500 \mu \mathrm{M})$ counteracted the decrease in GAP-43 levels produced by ODQ (Figure 4c; $95.5 \pm 12 \%$ of control values, $P<0.001$ ), it failed to impede the effect of ODQ on neurite outgrowth (Figure 4a).

As ODQ diminishes the amount of sGC protein in different cell types, ${ }^{25,26}$ we assessed the levels of $\mathrm{sGC} \beta 1$ in cells maintained for $22 \mathrm{~h}$ in the presence of ODQ, which was
$60 \pm 11 \%$ of the control level $(P<0.01)$ in semiquantitative western blots (Figure $4 d$ ). This decrease caused by ODQ could not be overcome by increasing intracellular cGMP on exposure to $8-\mathrm{Br}$-cGMP (72 $\pm 14 \%$ of control, $P<0.05)$. ODQ $(10 \mu \mathrm{M})$ also caused an impairment in neurite outgrowth and after $22 \mathrm{~h}$ in culture the proportion of cells that had no neurites increased twofold with respect to the control cells $(P<0.05)$. Conversely, the proportion of cells with multiple neurites diminished to $52 \pm 3.5 \% \quad(P<0.05)$ and the presence of 8-Br-cGMP $(500 \mu \mathrm{M})$ failed to significantly modify these effects. We assessed the intracellular cGMP content (basal or NO stimulated) in control or cells incubated with $10 \mu \mathrm{M}$ ODQ or $50 \mu \mathrm{M}$ ODQ for $22 \mathrm{~h}$ and the values were as follows: control (basal: $0.28 \pm 0.2 \mathrm{pmol} / 10^{5}$ cells; stimulated $(1 \mu \mathrm{M}$ DEANO, $5 \mathrm{~min}$ ): $5.5 \mathrm{pmol} / 10^{5}$ cells), ODQ $10 \mu \mathrm{M}$ (basal: $0.15 \pm 0.02 \mathrm{pmol} / 10^{5} \mathrm{cells}$, stimulated: $1.5 \mathrm{pmol} / 10^{5}$ cells) and ODQ $50 \mu \mathrm{M}$ (basal: $0.1 \pm 0.005 \mathrm{pmol} / 10^{5}$ cells, stimulated: $0.38 \pm 0.03 \mathrm{pmol} / 10^{5}$ cells).

The effect of maintaining cells for 5 days in the presence of ODQ was analyzed and these conditions produced similar effects to those observed with morpholino antisense 

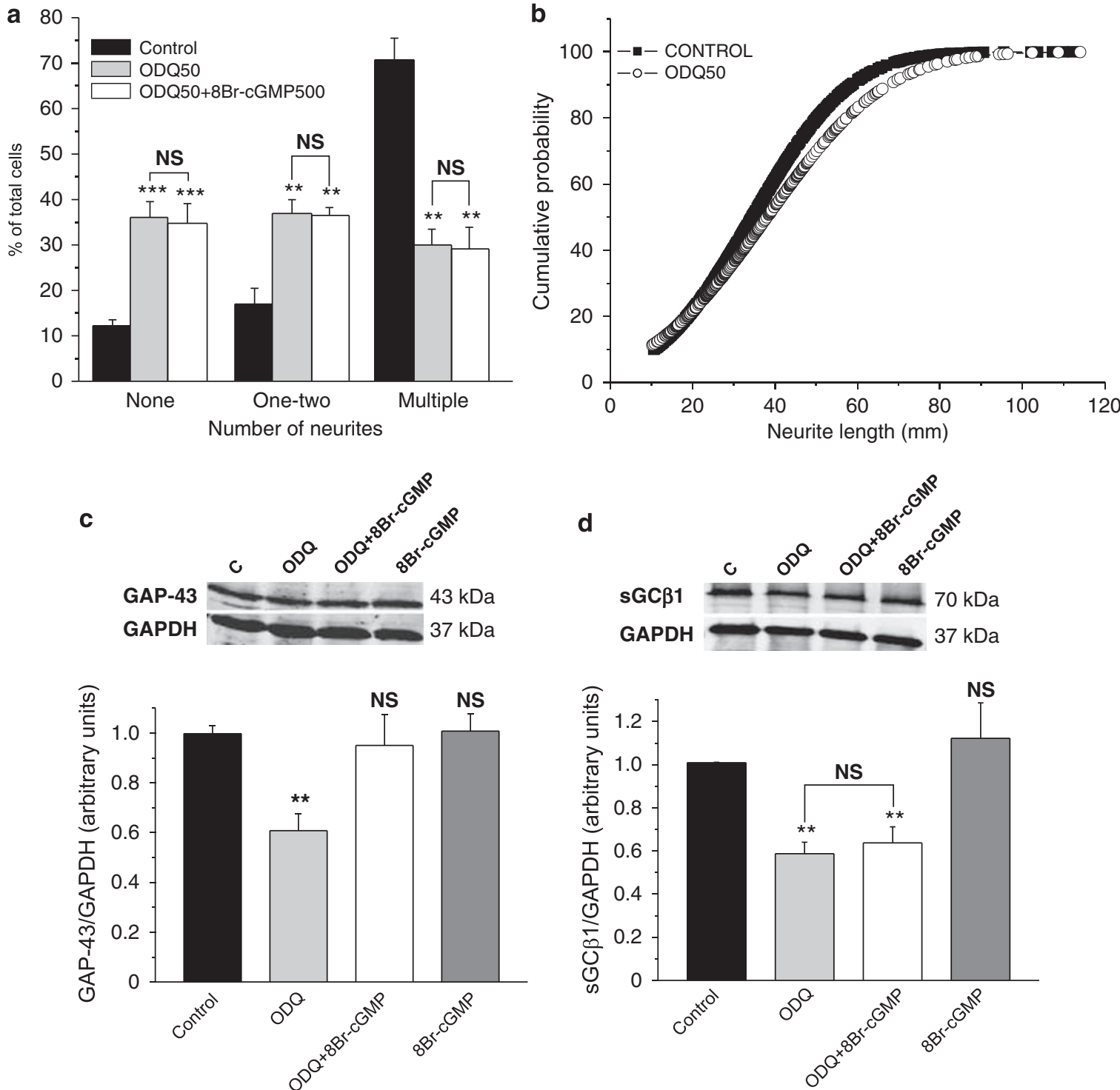

Figure 4 Inhibition of SGC impairs neurite outgrowth in cerebellar granule cells. (a) The percentage of cells (control or ODQ-treated cells) that emitted different numbers of neurites after $22 \mathrm{~h}$ in culture. Without neurites: control, $12.16 \pm 1.3 \%$; ODQ, $36 \pm 3.3 \%$; ODQ +8 -BrcGMP, $35 \pm 4 \%(P<0.001$, one-way ANOVA followed by Bonferroni test). One-two neurites: control, $17 \pm 3.7 \%$; ODQ, $33.7 \pm 4 \%$; ODQ + 8-BrcGMP, $37 \pm 1.4 \%$ ( $P<0.05$, one-way ANOVA followed by Bonferroni test). Multiple neurites: control, $71 \pm 5 \%$; ODQ; $30 \pm 3.3 \%$; ODQ + 8-BrcGMP, $29 \pm 5 \%(P<0.001$, one-way ANOVA followed by Bonferroni test); mean \pm S.E.M. of seven different cultures (control: 6567 cells, ODQ: 4594 cells, ODQ + 8-BrcGMP: 2627 cells). (b) Cumulative probability plots of neurite length in control (762 neurites) and ODQ-treated cells (374 neurites). The two plots are not significantly different ( $P>0.05$; Mann-Whitney U-test; $P>0.05$; Kolmogorov-Smirnov test). Quantification of GAP-43 (c) or sGC $\beta 1$ (d) levels after $22 \mathrm{~h}$ incubation with no treatment (control), $50 \mu \mathrm{M} \mathrm{ODQ}$ (ODQ), $50 \mu \mathrm{M}$ ODQ plus $500 \mu \mathrm{M}$ 8-Br-cGMP (ODQ + 8-Br-cGMP) or $500 \mu \mathrm{M}$ 8-Br-cGMP (8Br-cGMP). Membranes were stained with anti-guanylyl cyclase $\beta 1(1 \mu \mathrm{g} / \mathrm{ml}$, ER-19), anti-GAP-43 mouse monoclonal lgG $(1 \mu \mathrm{g} / \mathrm{ml})$ and anti-GAPDH mouse monoclonal lgG $(1 \mu \mathrm{g} / \mathrm{ml})$. The data represent the mean \pm S.E.M. from four different cultures (Significantly different from control values: ${ }^{* *} P<0.01$, one-way ANOVA followed by Bonferroni test). Upper panels: western blot probed for GAP-43, sGC $\beta 1$ and GAPDH in the same conditions

oligonucleotides. Indeed, over this period the morphology of the cell culture changed as the net of fibers became less dense and cell viability decreased to $69.7 \pm 6.2 \%$ (Figure $5 \mathrm{a}$ and $\mathrm{b} ; P<0.001$ ). Similarly, the level of $\mathrm{sGC} \beta 1$ expression dropped to $22 \pm 9 \%$ that of control cells $(P<0.001)$, whereas GAP-43 expression dropped to $44 \pm 10 \%$ that of the controls $(P<0.01)$. The fact that only the persistent inhibition of $\mathrm{SGC}$ had an effect on cell viability might be explained by an impairment of synaptogenesis, because neurons must establish functional synaptic contacts to remain viable. We checked whether cell death occurs through apoptosis by labeling the cultures with annexin $V 72 \mathrm{~h}$ after treatment, because exposure of phosphatidylserine on the cell surface is one of the first alterations in cells programmed to die. Exposure to ODQ increases by fourfold the percentage of cells labeled with annexin $\mathrm{V}$ and calcein-AM (control $1.18 \pm$ $0.32 \%$, ODQ-treated cells $4.01 \pm 0.93 \% ; P=0.01233, t$-test and $P=0.00977$, Mann-Whitney test), indicating that the integrity of their membranes remained intact despite the exposure of phosphatidylserine (Figure $5 \mathrm{c}$ ). 
a

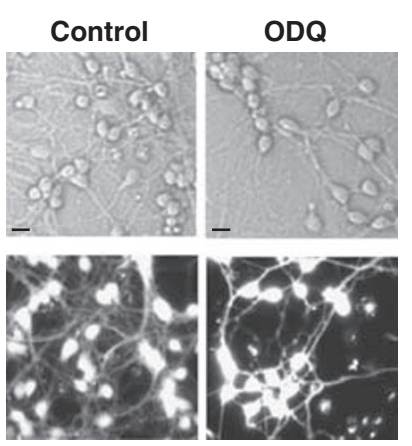

b

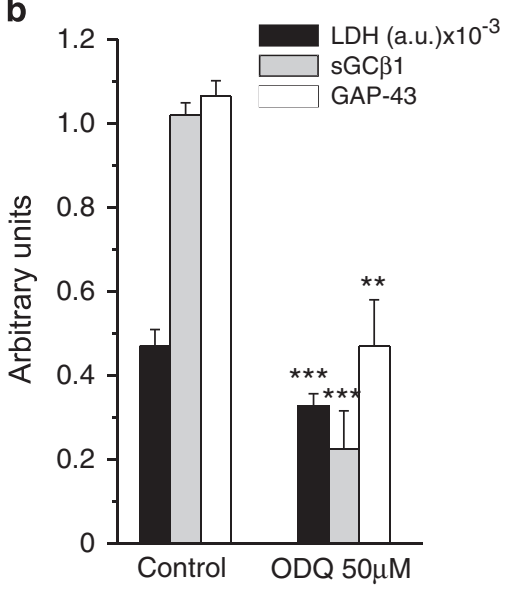

C Control cells

$87 \%$

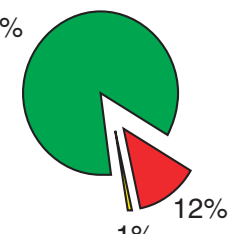

ODQ treated cells

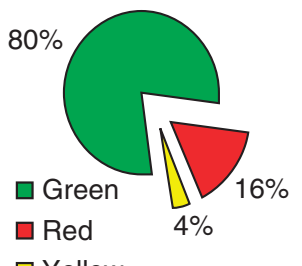

d

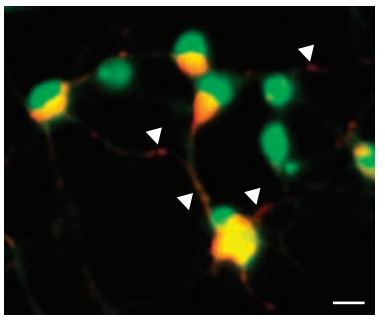

Figure 5 Sustained inhibition of SGC $\beta 1$ downregulates sGC $\beta 1$ and GAP-43 levels, and reduces cell viability. (a) Phase contrast image of cerebellar cells (upper panels) or fluorescence images of calcein-AM labeled cerebellar cells (lower panels) maintained for 5 days in culture under control conditions or in the presence of $50 \mu \mathrm{M}$ ODQ. Scale bars: $10 \mu \mathrm{m}$. (b) Viability is expressed as LDH activity in fluorescence arbitrary units (these values interpolated in a calibration plot correspond to control: $65981 \pm 7133$ and ODQ-treated cells $42911 \pm 5189$ ), and quantification of sGC $\beta 1$ and GAP-43 normalized to GAPDH after 5 days in culture. Staining was performed with anti-guanylyl cyclase $\beta 1$ (ER-19, $1 \mu \mathrm{g} / \mathrm{ml})$, anti-GAP-43 mouse monoclonal IgG $(1 \mu \mathrm{g} / \mathrm{ml})$ and anti-GAPDH mouse monoclonal lgG $(1 \mu \mathrm{g} / \mathrm{ml})$. The data represent the mean \pm S.E.M. of three different cultures (significant differences from control values are indicated: ${ }^{* *} P<0.001,{ }^{* \star} P<0.01,{ }^{\star} P<0.05$, one-way ANOVA). (c) Percentages of cell labeled with calceinAM (green), annexin V (red) and both (yellow) for control (991 cells analyzed, right panel; green: $86.45 \pm 2.18 \%$; red: $12.36 \pm 2.33 \%$ and yellow: $1.18 \pm 0.32 \%$ ) and ODQtreated cells (2041 cells analyzed, left panel; green: $80.1 \pm 3.09 \%$; red: $15.87 \pm 2.55 \%$ and yellow: $4.01 \pm 0.93 \%$ ). Data represent the mean of eight experiments from four different cultures. (d) Double staining cells with annexin $\mathrm{V}$ and calcein-AM showing apoptotic cells. Arrowheads point to the presence of annexin $\mathrm{V}$ labeling in the fibers. Scale bars: $10 \mu \mathrm{m}$

a

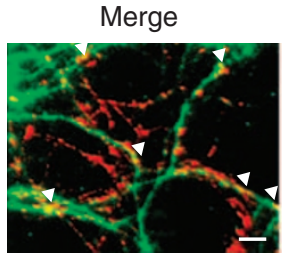

b

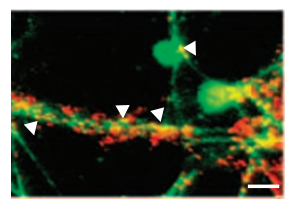

C

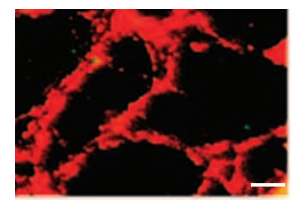

Basoon
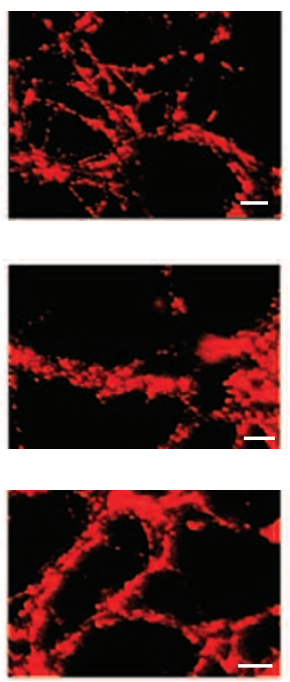

cGMP
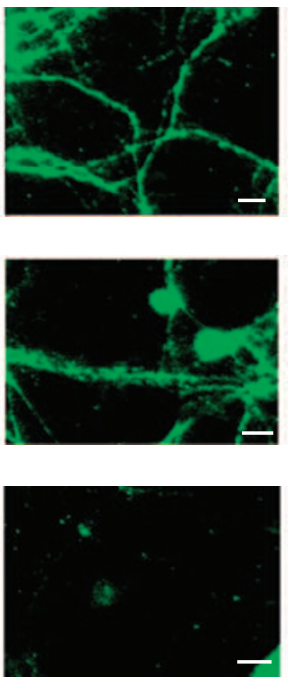
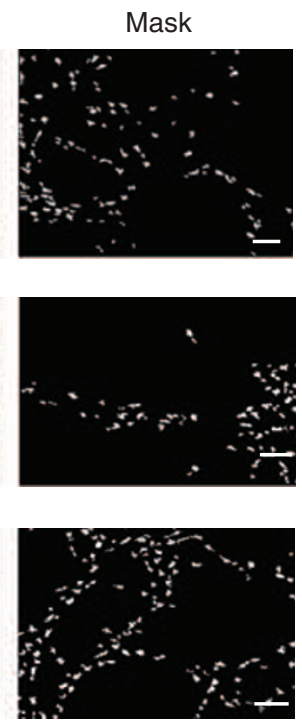

Figure 6 Presynaptic synthesis of cGMP. Cells were washed and incubated in the presence (a and $\mathbf{b})$ or absence (c) of $1 \mu \mathrm{M}$ DEA-NONOate for 5 min and then fixed and processed as described with a sheep anti-formaldehyde-fixed cGMP antibody 1:4000 (kindly provided by Dr. Jan de Vente, and with a guinea pig anti-bassoon antibody 1:500 (Synaptic System). Composite color image to illustrate the colocalization of the two signals (left panel), bassoon (middle panel, red), cGMP (middle panel, green), binary mask of bassoon positive terminals obtained with Igor Pro software. Arrowheads point to 'en passant synaptic boutons positive for bassoon and cGMP. Scale bars: $10 \mu \mathrm{m}$

The presence of guanylyl cyclase in neuronal processes and at synapses has been described in different cell types. ${ }^{6,12,27}$ A specific antibody against cGMP identified a large increase in this cyclic nucleotide in the soma and processes of the granule cells after nitric oxide stimulation (Figure 6). Indeed, some strongly labeled en passant boutons could also be observed along the axons, which colocalized with the presynaptic marker bassoon (colocalization 6997 out of 16875 boutons, which correspond to a $40.94 \pm 3.45 \%$ ). Hence, we wondered whether the downregulation of $\mathrm{sGC} \beta 1$, and the ensuing impairment in the capacity to produce cGMP, might affect synapse formation (the number of synaptic boutons) and their functionality. The number of synapsin I-positive puncta in neurites of granule cells was analyzed as 

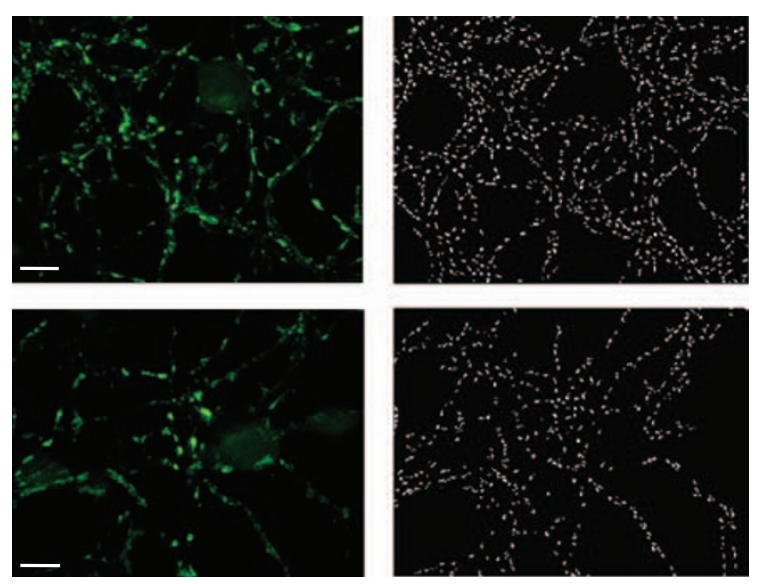

d

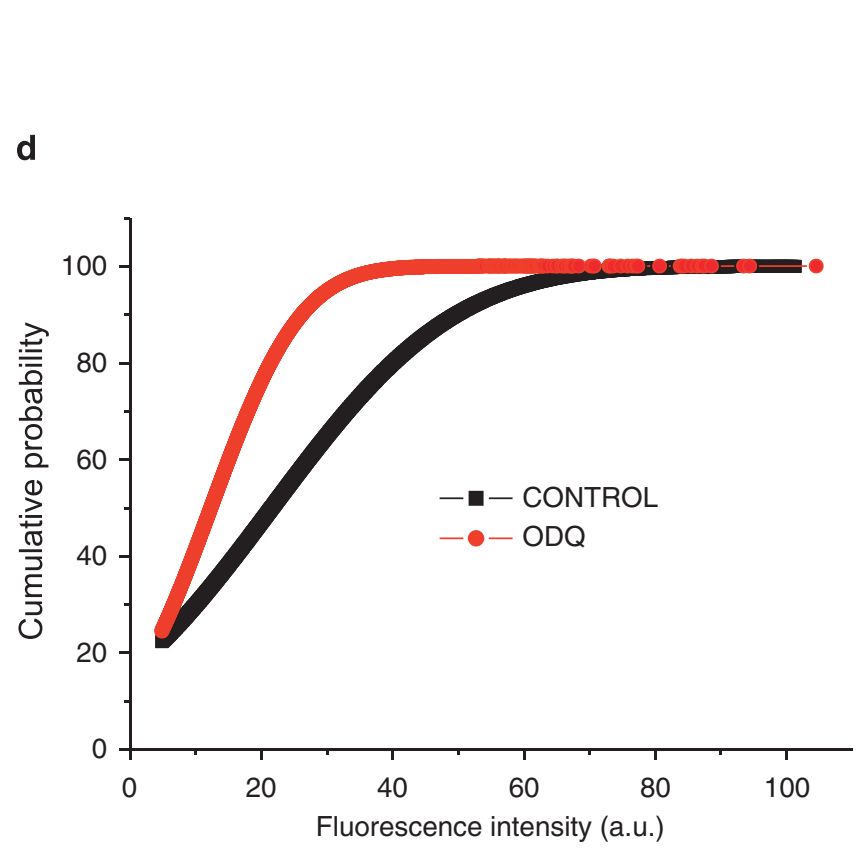

b

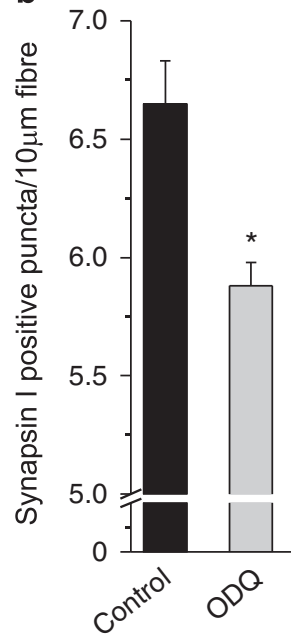

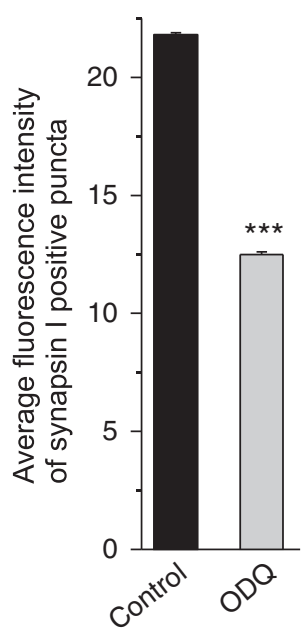

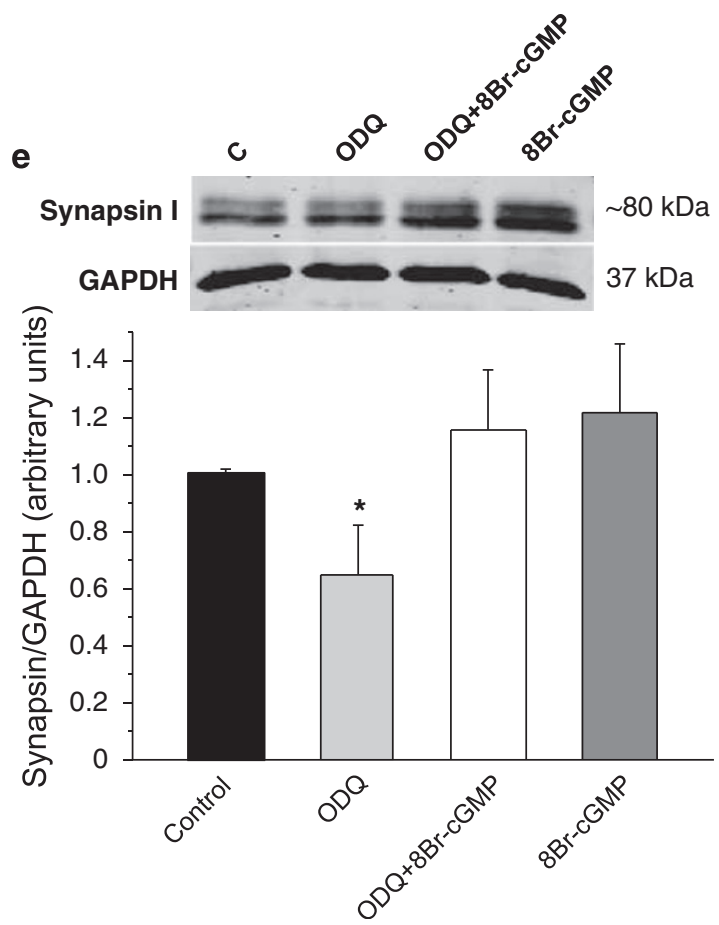

Figure 7 Persistent inhibition of SGC decreases the number of synaptic boutons. (a) Representative fluorescent micrographs showing granule cells labeled by a synapsin I-specific antibody in the absence (upper panels) and presence of ODQ (lower panels, scale bar $10 \mu \mathrm{m}$ ), and the correspondent mask of the terminals obtained with lgor Pro software (right panels). (b) Average number of boutons per $10 \mu \mathrm{m}$ of fiber. (c) Average fluorescence intensity of synapsin I-positive puncta. Data represent the mean \pm S.E.M. of different fields from different cultures (significant differences from controls are indicated as: ${ }^{* \star *} P<0.001 ;{ }^{*} P<0.05$, one-way ANOVA). (d) Cumulative probability plots of the fluorescence intensity in individual boutons (control: 34758 boutons, ODQ: 18215 boutons) labeled with synapsin, which are significantly different $(P<0.001$, Mann-Whitney U-test; $P<0.001$, Kolmogorov-Smirnov test). (e) Immunoblot analysis of extracts of granule cells cultured for 5 days alone (control), or with $50 \mu \mathrm{M} O D Q, 50 \mu \mathrm{M}$ ODQ plus $500 \mu \mathrm{M}$ 8-Br-cGMP or with $500 \mu \mathrm{M}$ 8-Br-cGMP. GAPH is a control for the total protein levels and the data represent the mean \pm S.E.M. of four different cultures $\left({ }^{*} P<0.05\right.$, one-way ANOVA followed by Bonferroni test)

an indicator of synaptic boutons (Figure 7a). When the number of synapsin I-positive puncta per $10 \mu \mathrm{m}$ of neurite length was assessed (Figure 7b), a small yet significant reduction in synapsin I-positive puncta was detected (from $6.7 \pm 0.2$ in control cells to $5.9 \pm 0.1$ in ODQ-treated cells: $P<0.05$, $n=30$ ). Furthermore, the intensity of synapsin I-positive puncta decreased more strongly in ODQ-treated cells (Figure $7 \mathrm{c}$ and d). The cumulative probability plots of the intensity of the individual puncta expressed in arbitrary fluorescence units shows clearly significant differences between control ( $n=31117$ boutons) and ODQ-treated cells $(n=14195$ boutons; Figure 7d; $P<0.001$; Mann-Whitney $U$-test and Kolmogorov-Smirnov test). Thus, inhibition of guanylyl cyclase not only affects the formation of new synapsin I clusters but it also decreases the amount of synapsin I in the boutons that do form. 
To determine whether ODQ affects synapsin I levels, we examined this protein in extracts of granule cell cultured for 5 days in the presence or absence of ODQ. Exposure to ODQ appreciably reduced the amount of synapsin I in immunoblots, although the presence of $8-\mathrm{Br}$-cGMP counteracted this effect (Figure 7e). Apart from playing a prominent role in the formation and maintenance of synaptic contacts between neurons, synapsin I also regulates neurotransmitter release. ${ }^{28}$ To directly measure the presynaptic function of synapsin I, we examined the ability of active granule cells to take up the fluorescent styryl dye FM1-43 into synaptic vesicles. FM1-43 was observed in synaptic puncta-like spots along neurites (Figure 8a). The initial levels of fluorescence increased slightly in ODQ-treated cells and 8-Br-cGMP prevented this increase $(20.34 \pm 0.44,25.05 \pm 0.53$ and $19.27 \pm 0.32$ arbitrary units, from 16 experiments with 1918 control, 2300 ODQ-treated boutons and 1268 ODQ plus 8-BrcGMP, respectively). Indeed, when the cumulative probability plots of the initial fluorescence of control or ODQ-treated boutons were analyzed, significant differences were observed (Figure 8b; $P<0.001$, Mann-Whitney $U$-test and Kolmogorov-Smirnov test). The normalized data indicated that two different populations of boutons could be distinguished according to the extent and rate of dye loss (Figure $8 \mathrm{c}-\mathrm{f})$. Although group 1 lost a large amount of the dye rapidly on depolarization, the group 2 boutons lost less fluorescent dye more slowly. In the control cells, group 1 boutons lost $71.9 \pm 1.5 \%$ of the initial dye load in the first $90 \mathrm{~s}$ after stimulation with a time constant $(\tau)$ of $8.1 \pm 1.2 \mathrm{~s}$, whereas group 2 boutons lost $40.7 \pm 1.8 \%$ with a $\tau$ of $16.5 \pm 2.5 \mathrm{~s}$ (the $\tau$ was significantly different between the two groups, $P<0.01$ ). Likewise, when cells were incubated in the presence of ODQ, group 1 boutons lost $63.4 \pm 1.8 \%$ of their dye with a $\tau$ of $7.6 \pm 1.4 \mathrm{~s}$ and group 2 boutons lost $34.0 \pm 2.9 \%$ with a $\tau$ of $15.1 \pm 2.6 \mathrm{~s}$ ( $\tau$ was significantly different between the two groups, $P<0.01)$. Although there was no difference in the rate of destaining $(\tau)$ in both control and ODQ-treated cells, both groups lost significantly less dye when exposed to ODQ (Figure 8f; group 1 control versus group $1 \mathrm{ODQ}, P<0.001$ and group 2 control versus group 2 ODQ, $P<0.001$; MannWhitney $U$-test and Kolmogorov-Smirnov test). The presence of $8-\mathrm{Br}-\mathrm{cGMP}$ partially prevented the decrease in dye lost caused by ODQ in group 2 but had no effect in group 1 (37.0 \pm $1.3 \%, P<0.01$, Mann-Whitney $U$-test and KolmogorovSmirnov test, significantly different from ODQ-treated cells). Furthermore, there was a significant difference in the percentage of boutons that specifically lost the dye after depolarization (Figure $8 \mathrm{~g}$ ), and complied with the quality standard of 0.1 when an automated approach to identify and classify the puncta was used. ${ }^{29}$ These boutons represented $44.3 \pm 2.0 \%$ of the total boutons detected in control cells and only $26.8 \pm 2 \%$ in cells exposed to ODQ $(P<0.001), 8-\mathrm{Br}-$ cGMP increased this value to $33.4 \pm 1.0 \%(P<0.05)$. Moreover, the proportion of boutons (of the total detected) that belong to group 1 or group 2 was also very different (Figure $8 \mathrm{~h}$ ), being $30.3 \pm 2.1$ and $14 \pm 2 \%$, respectively, for control cells; $10.3 \pm 0.6$ and $16.5 \pm 1.8 \%$, respectively, for ODQ-treated cells; $22.70 \pm 1.1$ and $10.65 \pm 0.8 \%$, respectively, for ODQ plus 8-Br-cGMP-treated cells. When the two populations were analyzed taking into consideration the boutons that fulfill the established quality criteria, significant differences were found in both groups. The percentage of boutons that belong to group 1 decreased by $42.6 \%$ in ODQtreated cells when compared to controls $(P<0.001)$, and the percentage of those belonging to group 2 increased by $94 \%$ following ODQ exposure (Figure 7i; $P<0.001$ ), these effects were completely prevented by the presence of 8-Br-cGMP. Thus, in ODQ-treated cells there were fewer boutons that fulfilled the established quality criteria and of the boutons that did, more belonged to group 2 .

\section{Discussion}

We show here that the activity of SGC is necessary for the development of cerebellar granule cells in culture. Moreover, we have been able to distinguish an early effect of reducing sGC $\beta 1$ on neurite outgrowth, as well as a later effect that impairs synapse formation and/or their maturation.

Immunocytochemistry for SGC $\beta 1$ produced diffuse labeling in the soma and along fibers. Moreover, cerebellar granule cells develop en passant boutons along axons that are strongly labeled for cGMP after stimulation with a NO donor, suggesting that cGMP is probably synthesized there. Although this experimental approach does not accurately define the location of SGC, these results indicate that active sGC is present in these presynaptic boutons, consistent with the presence of this enzyme in presynaptic terminals and close to the active zone. ${ }^{11,12,30}$ The presence of sGC in neuronal processes and in synaptic boutons would also explain its increased expression during development ${ }^{5}$ and its importance in regulating different steps of neuronal development.

Our results indicate that the knockdown or inhibition of the sGC protein has an early effect that can be observed within the first $22 \mathrm{~h}$ in culture and that involves impaired neurite outgrowth. This process can be defined as a three-step event in all neurons: first, the loss of the round shape of the cell and the generation of a filopodia-like extension; second, the elongation of this extension and its transformation into a true neurite; third and finally, the differentiation of the neurite into an axon or dendrite. ${ }^{31}$ The lack of sGC activity seems to affect the first two steps in this process because more round cells and fewer neurites per cell were evident after $22 \mathrm{~h}$ in culture. One of the first events during the initiation of neurite outgrowth is a rearrangement of the actin cytoskeleton, which is mediated by a plethora of actin remodeling proteins. A protein known to be involved in transducing intra- and extracellular signals that regulate cytoskeletal organization in the axonal growth cone is GAP-43, whose phosphorylation at Ser41 is essential for neurite elongation in primary neurons. ${ }^{32}$ This protein is essential for axonal growth and it participates in neurite branching, ${ }^{14}$ as well as in the formation of new synapses. ${ }^{16}$

Elevating cGMP levels by the application of 8 -Br-cGMP does not overcome the depletion of $s G C \beta 1$ observed in ODQtreated cells, which may indicate that the effect of ODQ on the sGC protein is due to ubiquitin-dependent protein degradation. Indeed, oxidation of SGC heme not only results in the loss of NO-sensitive SGC activity but also in ubiquitin-dependent sGC protein degradation. ${ }^{26}$ Bath application of 8-Br-cGMP 

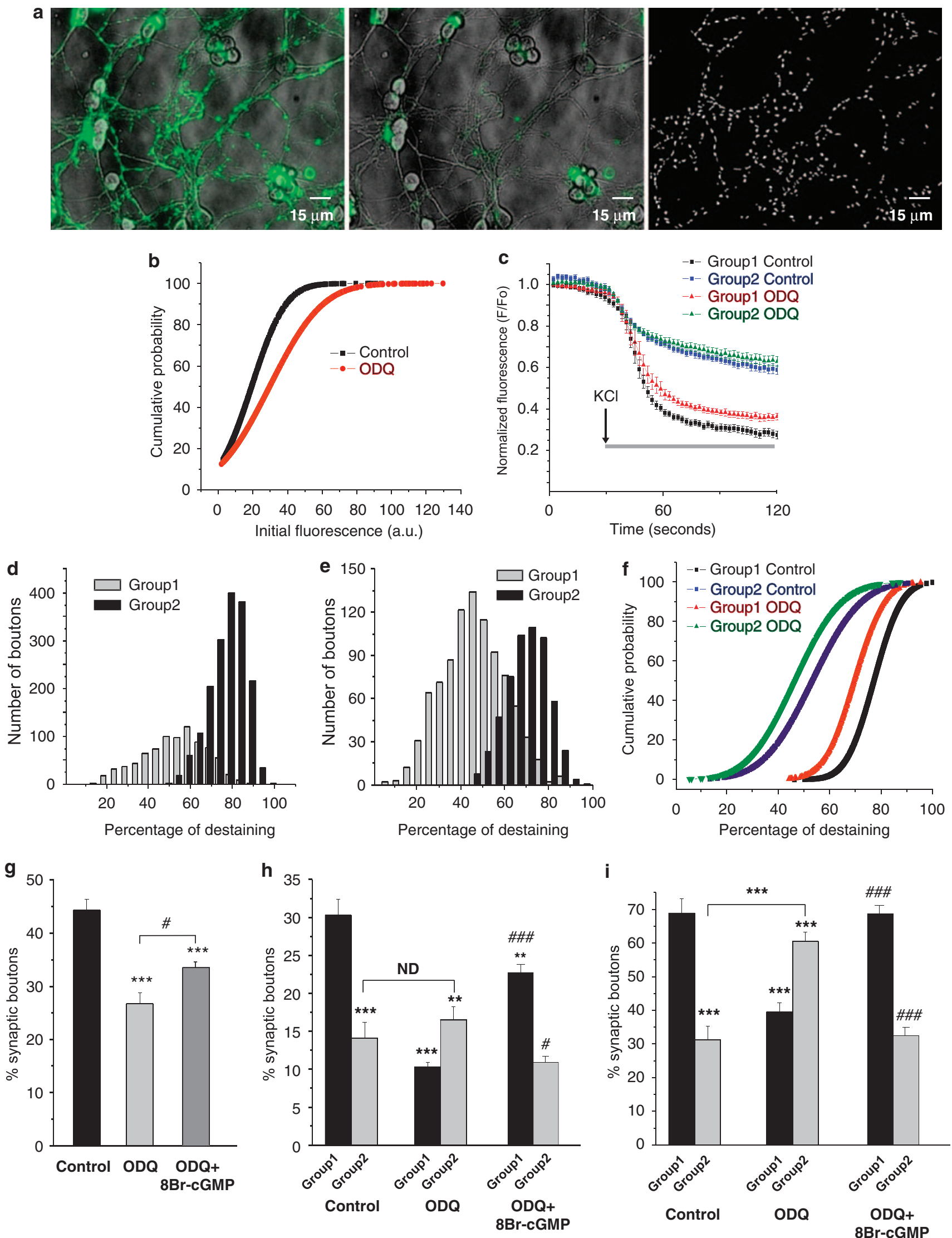
also failed to prevent the impaired neurite outgrowth caused by ODQ. As we cannot rule out an effect of ODQ on neurite outgrowth independent of the inhibition of soluble guanylyl cyclase, these results are difficult to interpret. Nevertheless, the impairment of neurite outgrowth caused by ODQ $(50 \mu \mathrm{M})$ is very similar to that observed when SGC was knockdown with siRNA. Moreover, the effect of ODQ is dose-dependent and it is related to its capacity to reduce intracellular cGMP levels. These observations lead us to speculate that the local intracellular synthesis of cGMP may be necessary to specifically activate the downstream signals involved in controlling neurite outgrowth.

Conversely, 8-Br-cGMP fully prevented the reduction in GAP-43 and synapsin I, indicating that their levels are regulated in a cGMP-dependent manner. The data available suggest a relationship between the CGMP pathway and GAP43 expression. ${ }^{33}$ In addition, GAP-43 mRNA expression is controlled by glutamatergic NMDA receptors, ${ }^{34}$ and the formation of NO and CGMP is one consequence of NMDA receptor stimulation. ${ }^{5,35}$ We previously demonstrated that NMDA receptor stimulation regulates the stability of different mRNAs via the NO/cGMP pathway, altering the levels of the AUF1 proteins that bind to and destabilize them. ${ }^{23}$ Such a process might be active in this paradigm as GAP-43 mRNA has a long $3^{\prime}$ UTR bearing specific determinant pyrimidinerich sequences that AUF1 can bind to, thereby destabilizing this mRNA. ${ }^{36} \mathrm{PC} 12$ cells degrade GAP-43 mRNA rapidly and through the NO/cGMP signaling pathway, NGF both increases its half-life ${ }^{37}$ and induces neurite outgrowth. ${ }^{4}$ However, according to our results a reduction in GAP-43 levels cannot explain the impairment of neurite outgrowth observed when guanylyl cyclase activity is suppressed, because $8-\mathrm{Br}$ cGMP restores GAP-43 levels but fails to counteract the impaired neurite emission. The involvement of other proteins may explain this effect because cGMP/cGK signaling may control cell shape in different cell models by regulating either the expression or activity of the RhoA GTPase. ${ }^{38,39}$ It is believed that RhoA suppresses neurite outgrowth ${ }^{31}$ and thus, an increase in RhoA activity in SGC $\beta$ 1depleted cells might also explain the inhibition of neurite outgrowth.

It is important to point out that none of the treatments applied to the cells affected their viability during the first 3 days, although there was a $30-40 \%$ reduction in the number of cells by day 5 . We attribute this cell death to the failure to form functional connections because it is well known that once neurons have grown to their targets, they either form synapses and establish the functional connections characteristic of the mature nervous system or they die. This interpretation is sustained by the fact that cell death occurs by apoptosis, through the reduction in the levels and/or intracellular redistribution of two proteins clearly involved in synaptogenesis, GAP-43 and synapsin $1,{ }^{16,17}$ and by the altered synaptic functionality. In the assays performed with the styryl dye FM1-43, we found that inhibition of sGC leads to a large decrease in the number of functional boutons (those fulfilling the established quality criteria) and a slowing of vesicle recycling. Indeed, a higher proportion of boutons exhibited slower kinetics and displayed less dye loss when sGC is inhibited, suggesting that most of the loaded vesicles do not complete the exo-endocytosis cycle within the experimental period. As the culture matured, the number of functional boutons increased, and the majority of these boutons develop rapid kinetics and significant dye loss (unpublished results). Thus, the small proportion of functional boutons and the high proportion of boutons that display slow vesicle recycling are characteristics of immaturity. This delay in maturation might be due to the decrease in synapsin I or GAP-43 expression observed in ODQ-treated cells, particularly because these proteins have been proposed to fulfill a role in synapse formation during development and their expression correlates well with the maturation of synapses. ${ }^{17}$ Synapsins can also regulate the availability of vesicles for exocytosis, ${ }^{19}$ and indeed, they are required to establish a reserve pool of vesicles that facilitates the efficient recruitment of vesicles to the active zone and that maintains the high rate of neurotransmitter release during synaptic transmission. ${ }^{20}$ Hence, a decrease in the levels of synapsins could account for the slowing of vesicle release in cells in which SGC is inhibited, although other possibilities cannot be ruled out. ${ }^{40}$ Our data indicate that SGC activity is an important element not only in neurite outgrowth but also in synapse formation and maturation in cerebellar granule cells. This information clearly contrasts with data from the rat cerebral cortex where the NO/cGMP pathway seems to play a role in dendritic development but not in synaptogenesis. ${ }^{7}$ Although differences in neuronal types and the use of different models could account for these discrepancies, further studies should help to clarify the involvement of sGC in synapse formation and maturation.

\section{Materials and Methods}

Antibodies. The primary antibodies used here were as follows: a rabbit antiguanylyl cyclase $\beta 1$ soluble (ER-19; Sigma) ${ }^{41}$ a mouse monoclonal anti-synapsin I

Figure 8 Persistent inhibition of guanylyl cyclase affects synaptic function. (a) Superposition of the phase contrast image and fluorescence image before (left) and after (middle) the experiment. Right panel: mask of terminals obtained with Igor Pro software. Bars $15 \mu \mathrm{m}$. (b) Cumulative probability plots of initial fluorescence intensity of the boutons that fulfill the quality requirement of 0.1 with the Bergsman routine (see Materials and Methods) (control $n=1918$ boutons versus ODQ $n=1585 ; P<0.001$, MannWhitney U-test and Kolmogorov-Smirnov test). (c) Kinetics of FM1-43 $(10 \mu \mathrm{M})$ dye loss during sustained stimulation with $50 \mathrm{mM} \mathrm{KCl}$ (control $n=1918$ boutons, ODQ $n=2300$ boutons). (d) Frequency histogram of the destaining after $2 \mathrm{~min}$ of stimulation demonstrating the existence of two groups in control cells. (e) Frequency histogram of the destaining after $2 \mathrm{~min}$ of stimulation showing the existence of two groups in ODQ-treated cells. (f) Cumulative probability plots of the destaining of the two groups in control or ODQ-treated cells (group 2 control versus group $2 \mathrm{ODQ} P<0.001$; group 1 control versus group $1 \mathrm{ODQ}, P<0.001$; group 1 control versus group 2 control $P<0.001$ and grupo1 ODQ versus group 2 ODQ $P<0.001$, Mann-Whitney U-test and Kolmogorov-Smirnov test). (g) Percentage of synaptic boutons that fulfill the 0.1 criteria and that specifically releases the dye during depolarization. (h) Percentage of all detected synaptic boutons that belong to group 1 (fast kinetic) or group 2 (slow kinetic). (i) Percentage of boutons that are of quality 0.1 and that belong to group 1 (fast dye release kinetics) or group 2 (slow dye release kinetics). The data represent the results of 16 different experiments from ten different cultures for control and ODQ, and 6 experiments from 4 different cultures for ODQ plus 8-Br-cGMP. Data in (g), (h) and (i) are expressed as the mean \pm S.E.M. (significant difference from control values is indicated: ${ }^{\star \star \star} P<0.001$, ${ }^{\star *} P<0.01$, significant difference from ODQ-treated cells values is indicated: \#\#\# $P<0.001$, ${ }^{\#} P<0.05$, $t$-test and Welch test) 
(Synaptic System); a mouse monoclonal anti-GAP-43 IgG (Zymed Laboratories); a mouse monoclonal anti-GAPDH IgG (Ambion); an anti-Bassoon guinea pig polyclonal antiserum (Synaptic System) or a sheep anti-formaldehyde-fixed cGMP antibody (kindly provided by Dr. Jan de Vente). The appropriate secondary antibodies used were a Cy3-conjugated affinity purified donkey antirabbit $\lg G(H+L)$, a Cy2-conjugated affinity purified donkey anti mouse $\lg G(H+L)$ or a Cy2-conjugated affinity purified donkey anti-sheep $\lg G(H+L$; Jackson ImmunoResearch).

Cell culture. All procedures relating to the care of animals were carried in accordance with our institute's ethical guidelines for animal experiments and the regulations established in the European Council Directive (86/609/EEC). Primary dissociated cerebellar cultures were established using the cerebellum from 7-dayold (P7) male or female Wistar albino rat pups according to previously described methods. ${ }^{5}$ Cerebellar cells were diluted in Neurobasal A supplemented with B27 (Invitrogen), $20 \mathrm{mM} \mathrm{KCl}, 0.5 \mathrm{mM}$ glutamine and the stabilized antibiotic antimycotic solution (Sigma). The cells were seeded onto poly-L-lysine-coated coverslips, or in 96- or 6-well tissue culture plates, at a density of $1-3 \times 10^{5}$ cells/coverslip, $2 \times 10^{5}$ or $3.5 \times 10^{6} \mathrm{cells} /$ well, respectively. The cultures were maintained in a humidified incubator in $5 \% \mathrm{CO}_{2}$ at $37^{\circ} \mathrm{C}$ and after $24 \mathrm{~h}$ in culture, $10 \mu \mathrm{M}$ cytosine- $\beta$-Darabinofuranoside was added to restrict glial cell growth.

Cell transfection. Dissociated neurons were transfected with $1.5 \mu \mathrm{g}$ of siRNA designed to knockdown the expression of the $\beta 1$ subunit of guanylyl cyclase (sGC$\beta 1$ siRNA (r):sc-60102; Santa Cruz Biotechnology) or with a control (nonsilencing) siRNA (sense: UUC UCC GAA CGU GUC ACG UdTdT, antisense: ACG UGA CAC GUU CGG AGA AdTdT; predicted Target DNA sequence: AAT TCT CCG AAC GTG TCA CGT). All transfections of cerebellar granule cells were performed with a Nucleofector device using the 0-03 program and the corresponding kits (Amaxa), according to the manufacturer's instructions. First, we optimized the transfection program for cerebellar granule cells. In brief, $5 \times 10^{6}$ granule cells were incubated in $100 \mu \mathrm{l}$ of rat neuron nucleofection solution for primary mammalian neural cells containing $2 \mu \mathrm{g}$ of pmax GFP (green fluorescent protein from copepod Pontellina $\mathrm{p}$ ), using five different Nucleofector programs: A-33, C-13, G-13, 0-03 and 0-05. The maxGFP-expressing cells were examined after 24 and $48 \mathrm{~h}$ by inverted fluorescent microscopy using a Nikon Diaphot microscope equipped with a $40 \times 1.3$ numerical aperture (NA) or $100 \times 1.3$ (NA) oil immersion fluor objectives, a mercury lamp light source and fluorescein filter. Images were obtained using a slow-scan CCD camera (Hamamatsu C4880) operating at 12-bit digitalization (4096 levels) and the output from the camera was stored using a computerized imaging system (Kinetic Imaging Ltd). The two programs that resulted in the highest transfection efficiency $(\sim 60 \%)$ with the lowest mortality (less than $35 \%$ ) were $0-03$ and $\mathrm{G}-13$, and $0-03$ was selected to use in the subsequent experiments. When $1.5 \mu \mathrm{g}$ of siRNA against pmaxGFP was included the expression of GFP was reduced by $95-98 \%$.

Cells were also transfected with morpholino antisense oligonucleotides against the soluble guanylyl cyclase $\beta 1$ subunit gene (MO- $\beta 1$ ) $5^{\prime}$-GGC ATG GTT CAC AAA ACC GTA CAT G-3', in which the sequence complementary to the predicted start codon is underlined. The morpholine oligonucleotide used as a control was the inverse of the antisense $5^{\prime}$-GTA CAT GCC AAA ACA CTT GGT ACG G-3'. In this case morpholino oligos $(1.5 \mu \mathrm{M})$ were delivered into the cells with $3 \mu \mathrm{l} / \mathrm{ml}$ endo-porter (Gene Tools).

RT-PCR and real-time RT-PCR reactions. Total RNA was extracted from cells using the RNeasy kit (Qiagen) and the RNA was quantified using the RiboGreen RNA Quantification Kit (Invitrogen) as described previously. ${ }^{25}$ RT-PCR reactions were performed in two steps as described previously. ${ }^{5}$ Firststrand CDNA was synthesized with MultiScribe reverse transcriptase (Applied Biosystems) in RT buffer containing $5.5 \mathrm{mM} \mathrm{MgCl}_{2}, 500 \mu \mathrm{M}$ of each dNTP, $2.5 \mu \mathrm{M}$ random hexamers, $0.4 \mathrm{U} / \mathrm{ml}$ RNAse inhibitor and $3.125 \mathrm{U} / \mathrm{ml}$ MultiScribe reverse transcriptase. The reactions were performed in a final volume of $50 \mu \mathrm{l}$ containing $1 \mu \mathrm{g}$ of RNA and a $10 \mathrm{~min}$ incubation at $25^{\circ} \mathrm{C}$ was employed to maximize primerRNA template binding. Reverse transcription was carried out at $48^{\circ} \mathrm{C}$ for $30 \mathrm{~min}$ and the reverse transcriptase was inactivated before performing the PCR reactions by heating the samples at $95^{\circ} \mathrm{C}$ for $5 \mathrm{~min}$. The specific PCR primers and the probe for the guanylyl cyclase $\beta 1$ subunit were designed on the basis of the published sequence (accession number NM_012769: forward, base position $17345^{\prime}$-TCC GAA TAT ACA TAC AGG TGT CTC AT-3'; reverse, base position 1857 5'-GGA TAG AAA CCA GAC TTG CAT TGG-3'; TaqMan probe, base position 1827 $5^{\prime}$-(FAM)-TCT TGC CCT TCA TGG ACA CAG GAC CT-(TAMRA)-3'). 18S rRNA was used as an endogenous control. To amplify a $200 \mathrm{bp}$ fragment, a commercial mixture of primers was used and a TaqMan probe labeled with VIC and TAMRA at the $5^{\prime}$ and $3^{\prime}$ ends, respectively (Applied Biosystems). PCR reactions were followed in a 9800 Fast Thermal Cycler (Applied Biosystems) with TaqMan Gold PCR reagents.

Immunocytochemistry. Cerebellar granule cells were plated on poly-Llysine-coated coverslips at a density of 100000 cells/coverslip. The attached cells were rinsed twice with PBS, fixed with $4 \%$ formaldehyde in PBS for $15 \mathrm{~min}$ at room temperature, briefly rinsed twice with TBS and then permeabilized with $0.2 \%$ Triton $\mathrm{X}$-100 for $6 \mathrm{~min}$. The cells were then blocked with TBS containing $0.05 \%$ Triton X100 and $10 \%$ normal donkey serum for $1 \mathrm{~h}$ at $37^{\circ} \mathrm{C}$, and they were then incubated for $24 \mathrm{~h}$ at $4{ }^{\circ} \mathrm{C}$ with the primary antibodies diluted in TBS containing $5 \%$ normal donkey serum and $0.05 \%$ Triton X-100. After washing the coverslips, they were incubated with fluorescent secondary antibodies $(1: 200)$ in TBS containing $5 \%$ normal donkey serum and $0.05 \%$ Triton X-100. Following several washes in PBS, the coverslips were mounted with prolong antifade (Invitrogen) and the cells were viewed with a Nikon Diaphot microscope equipped with $40 \times 1.3$ (NA) or $100 \times 1.3$ (NA) oil immersion fluor objectives, a mercury lamp light source and fluorescein or rhodamine Nikon filter sets. Images were obtained using a slow-scan CCD camera (Hamamatsu C4880) operating at 12-bit digitalization (4096 levels) and the camera output was stored using a computerized imaging system (Kinetic Imaging Ltd).

For control staining to confirm the specificity of the antibodies used, the cells were incubated with the secondary antibodies alone in the absence of primary antibodies.

For cGMP and bassoon colocalization analysis different fields from different preparations staining with bassoon and cGMP have been analyzed. Background subtraction and synaptic bouton identification (ROIs; regions of interest) was carried out with the Igor Pro software, and spurious ROls (those show a fluorescence intensity lower than twofold the background and those are not along dendrites) were removed manually. A binary mask is created with the image staining with bassoon and that was superposed on the image staining with cGMP after background subtraction and then analyzed for coincidence, the ROls of bassoon that are superposed to a soma have been removed. As in the case of bassoon, only ROls with fluorescence intensity twice the background have been considered positive and 6997 boutons out of 16875 were positive for bassoon and cGMP.

Western blotting. The protein extracts were separated on $8-10 \%$ sodium dodecyl sulfate-polyacrylamide gels and electrophoretically transferred to polyvinylidene difluoride membranes as described previously. ${ }^{21}$ The membranes were probed with the appropriate antibodies and the immunoreactive proteins were compared by densitometric measurement of the band intensities. The GAPDH signal was used to normalize for loading differences.

Neurite outgrowth assay. To test the effects of the pharmacological inhibitors or guanylyl cyclase $\beta 1$ knockdown on granule cell development in culture, recently isolated neurons were incubated in the presence of $\mathrm{ODQ}(10$ or $50 \mu \mathrm{M})$ or they were transfected with siRNA before they were assessed $22 \mathrm{~h}$ later. The cells were fixed and stained with crystal violet as described by Appel et $\mathrm{al}^{42}$ and images were obtained as described above to count the neurites blind to the experimental conditions. The number of neurites per cell was measured manually in different fields and only extensions longer than $15 \mu \mathrm{m}$ (longer that one cell diameter) were considered as neurites. Individual neurite length was measured in different fields using Image $\mathrm{J}$ software and only extensions of cells that did not contact with other extensions or cells were measured. For statistical analysis, the lengths of the individual neurites from control cells or from treated cells were compared.

Viability. Cell viability was determined by measuring the either cellular lactate dehydrogenase (LDH) content using a commercial fluorimetric kit (CytoTox-ONE; Promega) or with a MTT-based assay (CellTiter $96 \mathrm{AQ}_{\text {ueous }}$ One Solution Cell Proliferation Assay; Promega), which measures MTS (a water soluble analogue of MTT) reduction.

Calcein-AM labeling. After washing twice, cells were incubated for $10 \mathrm{~min}$ at $37^{\circ} \mathrm{C}$ with calcein-AM $250 \mathrm{nM}$ (Invitrogen) as described previously. ${ }^{5}$ Live cells were identified by the presence of the ubiquitous intracellular esterase, detected by the enzymatic conversion of the virtually nonfluorescent, cell-permeable calcein-AM to the intensely fluorescent calcein. The polyanionic dye calcein is retained within live cells and it produces intense, uniform green fluorescence (ex/em $495 \mathrm{~nm} / 515 \mathrm{~nm}$ ). 
Background fluorescence levels are inherently low with this assay technique, because the dye is virtually nonfluorescent before interacting with cells. Cell images were obtained as described above.

Apoptosis. Apoptosis was evaluated with the annexin V-PE apoptosis detection kit (Merk), which detects the cell membrane alterations that accompany programmed cell death. In normal viable cells, phosphatidylserine (PS) is located in the cytoplasmic surface of the cell membrane. On induction of apoptosis, rapid alterations in the organization of phospholipids occur, leading to exposure of PS at the cell surface. Detection of externalized PS can be achieved through interaction with the anticoagulant annexin $\mathrm{V}$, which can be assayed by fluorescence microscopy with a rhodamine filter.

To distinguish apoptotic cells from necrotic cells, the cultures were also incubated with calcein-AM as described above and only those cells labeled with calcein-AM (impermeable membranes) and annexin V (externalized PS) were considered apoptotic.

Synaptic bouton number. The number of synaptic boutons was determined by immunocytochemistry using an anti-synapsin I antibody. Synapsin I is probably the most specific marker of synapses in the central and peripheral nervous system. Cells cultured on coverslips for 5 DIV (control or ODQ-treated cells) were fixed and processed as described above for immunocytochemistry. The best fluorescence intensities were established for image acquisition with a randomly selected field and they remained constant during measurement.

To quantify the changes in immunoreactivity, we compared 60 randomly selected fields of control or ODQ-treated cells from different preparations. Background subtraction and synaptic bouton identification (ROIs) was carried out with the Igor Pro software, and spurious ROls were removed manually. ${ }^{29}$ Staining intensities were measured as gray-scale values (ranging from 0 to 255) using the Image $\mathrm{J}$ software and the average gray value was calculated by summing the gray values of each pixel divided by the total number of pixels. The mean values were used to compare signal intensities between control and ODQ-treated cells.

Synaptic bouton functionality (FM1-43). We analyzed endo-exocytosis as a measure of synaptic bouton function. The strategy is based on the uptake and unloading of the styryl dye FM1-43 in granule cells plated on coverslips. Cells were incubated for $10 \mathrm{~min}$ in calcium-free and low potassium buffer $(140 \mathrm{mM} \mathrm{NaCl}, 5 \mathrm{mM}$ $\mathrm{KCl}, 5 \mathrm{mM} \mathrm{NaHCO}, 1.2 \mathrm{mM} \mathrm{NaH}_{2} \mathrm{PO}_{4}, 1 \mathrm{mM} \mathrm{MgCl}, 10 \mathrm{mM}$ glucose, $10 \mathrm{mM}$ HEPES, pH 7.4). They were then incubated with $10 \mu \mathrm{M} \mathrm{FM1-43} \mathrm{dye} \mathrm{(Invitrogen)} \mathrm{in}$ high potassium buffer ( $10 \mathrm{mM}$ Hepes-NaOH pH 7.4, $95 \mathrm{mM} \mathrm{NaCl}, 50 \mathrm{mM} \mathrm{KCl}, 1 \mathrm{mM}$ $\mathrm{MgCl}_{2}, 5 \mathrm{mM} \mathrm{NaHCO}, 1.2 \mathrm{mM} \mathrm{NaH}_{2} \mathrm{PO}_{4}, 1.33 \mathrm{mM} \mathrm{CaCl}_{2}, 10 \mathrm{mM}$ glucose) for $5 \mathrm{~min}$, followed by a $10 \mathrm{~min}$ wash by perfusion with a calcium-free low potassium buffer to remove the surface-bound dye $\left(140 \mathrm{mM} \mathrm{NaCl}, 5 \mathrm{mM} \mathrm{KCl}, 5 \mathrm{mM} \mathrm{NaHCO}_{3}\right.$ $1.2 \mathrm{mM} \mathrm{NaH}_{2} \mathrm{PO}_{4}, 1 \mathrm{mM} \mathrm{MgCl}, 10 \mathrm{mM}$ glucose, $10 \mathrm{mM}$ HEPES, pH 7.4). A more hydrophilic analogue, FM2-10, was also used, which produced similar background staining and destaining kinetics, and in both cases the signal to noise ratio was higher than two. Images were taken every $2 \mathrm{~s}$ with a Nikon microscope equipped with a Nikon $40 \times 1.3(\mathrm{NA})$ oil-immersion objective. Excitation was provided by a 479-nm monochromator and emitted light was collected using a fluorescein isothiocyanate (FITC) filter. Different fields were selected randomly and individual boutons were analyzed. Background subtraction and synaptic bouton identification (ROIs) were carried out with Igor Pro software. The analysis was performed according to the automated method described by Bergsman et al. ${ }^{29}$ with a minimum quality criterion for analysis of 0.1 . This criterion is established according to three measurements: the coefficient of variation (CV) of the baseline, the slope of the baseline and the final extent of destaining.

cGMP measurement. cGMP was measured with the HTRF-based assay from Cisbio Bioassays following the manufacturer's instructions. The cGMP assay is a competitive immunoassay that uses $\mathrm{Eu}^{3+}$ cryptate-labeled anti-cGMP and d2labeled cGMP.

Statistical analysis. The data were analyzed with the Statgraphic statistical software and the specific test applied in each case is indicated in the figure legend or the text. Differences were considered statistically significant when $P<0.05$, with a confidence limit of $95 \%$.

Acknowledgements. This study was financed by a grant from the Ministerio de Educación y Ciencia (BFU2006-01012/BFI), the Ministerio de Sanidad y Consumo (RD06/0026/0001), the Comunidad de Madrid (S-BIO-0170/2006), and the UCM-CAM (CCG07-UCM/SAL-2150). ME López-Jiménez was supported by a fellowship from UCM. We thank Dr. Castro for help with the software optimization for the FM1-43 experiments, Dr. de Vente for providing us with the anti-cGMP antibody and Dr. M Sefton for editorial assistance.

1. Polleux F, Morrow $T$, Ghosh A. Semaphorin $3 A$ is a chemoattractant for cortical apical dendrites Nature 2000; 404: 567-573.

2. Schmidt H, Stonkute A, Juttner R, Schaffer S, Buttgereit J, Feil R et al. The receptor guanylyl cyclase Npr2 is essential for sensory axon bifurcation within the spinal cord. J Cell Biol 2007; 179: 331-340.

3. Schmidt H, Werner M, Heppenstall PA, Henning M, More MI, Kuhbandner S et al. cGMPmediated signaling via cGKI alpha is required for the guidance and connectivity of sensory axons. J Cell Biol 2002; 159: 489-498.

4. Yamazaki M, Chiba K, Mohri T. Differences in neuritogenic response to nitric oxide in PC12 and PC12h cells. Neurosci Lett 2006; 393: 222-225.

5. Jurado S, Sánchez-Prieto J, Torres M. Differential expression of NO-sensitive guanylyl cyclase subunits during the development of rat cerebellar granule cells: regulation via N-methyl-D-aspartate receptors. J Cell Sci 2003; 116: 3165-3175.

6. Bidmon HJ, Mohlberg H, Habermann G, Buse E, Zilles K, Behrends S. Cerebellar localization of the NO-receptive soluble guanylyl cyclase subunits-alpha(2)/beta (1) in nonhuman primates. Cell Tissue Res 2006; 326: 707-714.

7. Ding JD, Burette A, Weinberg RJ. Expression of soluble guanylyl cyclase in rat cerebral cortex during postnatal development. J Comp Neurol 2005; 485: 255-265.

8. Mizuhashi S, Nishiyama N, Matsuki N, Ikegaya Y. Cyclic nucleotide-mediated regulation of hippocampal mossy fiber development: a target-specific guidance. J Neurosci 2001; 21: 6181-6194.

9. Van Wagenen S, Rehder V. Regulation of neuronal growth cone filopodia by nitric oxide depends on soluble guanylyl cyclase. J Neurobiol 2001; 46: 206-219.

10. Russwurm M, Behrends S, Harteneck $C$, Koesling D. Functional properties of a naturally occurring isoform of soluble guanylyl cyclase. Biochem J 1998; 335: 125-130.

11. Russwurm M, Wittau N, Koesling D. Guanylyl cyclase/PSD-95 interaction: Targeting of the nitric oxide-sensitive alpha2beta1 guanylyl cyclase to synaptic membranes. J Biol Chem 2001; 276: 44647-44652.

12. Burette A, Zabel U, Weinberg RJ, Schmidt HH, Valtschanoff JG. Synaptic localization of nitric oxide synthase and soluble guanylyl cyclase in the hippocampus. $J$ Neurosci 2002; 22: 8961-8970.

13. Wykes V, Garthwaite J. Membrane-association and the sensitivity of guanylyl cyclasecoupled receptors to nitric oxide. Br J Pharmacol 2004; 141: 1087-1090.

14. Lalli G, Hall A. Ral GTPases regulate neurite branching through GAP-43 and the exocyst complex. J Cell Biol 2005; 171: 857-869.

15. Skene JH. Axonal growth-associated proteins. Annu Rev Neurosci 1989; 12: 127-156.

16. Benowitz LI, Routtenberg A. GAP-43: an intrinsic determinant of neuronal development and plasticity. Trends Neurosci 1997; 20: 84-91.

17. Lu B, Czernik AJ, Popov S, Wang T, Poo MM, Greengard P. Expression of synapsin I correlates with maturation of the neuromuscular synapse. Neuroscience 1996; 74 : 1087-1097.

18. De Camilli P, Benfenati F, Valtorta F, Greengard P. The synapsins. Annu Rev Cell Biol 1990; 6: 433-460.

19. Jovanovic JN, Benfenati F, Siow YL, Sihra TS, Sanghera JS, Pelech SL et al. Neurotrophins stimulate phosphorylation of synapsin I by MAP kinase and regulate synapsin I-actin interactions. Proc Natl Acad Sci USA 1996; 93: 3679-3683.

20. Hilfiker S, Pieribone VA, Czernik AJ, Kao HT, Augustine GJ, Greengard P. Synapsins as regulators of neurotransmitter release. Philos Trans R Soc Lond B Biol Sci 1999; 354: 269-279.

21. Jurado S, Sánchez-Prieto J, Torres M. Elements of the nitric oxide/cGMP pathway expressed in cerebellar granule cells: biochemical and functional characterisation. Neurochem Int 2004; 45: 833-843.

22. Contestabile A. Roles of NMDA receptor activity and nitric oxide production in brain development. Brain Res Brain Res Rev 2000; 32: 476-509.

23. Jurado S, Rodríguez-Pascual F, Sánchez-Prieto J, Reimunde FM, Lamas S, Torres M. NMDA induces post-transcriptional regulation of alpha2-guanylyl-cyclase-subunit expression in cerebellar granule cells. J Cell Sci 2006; 119: 1622-1631.

24. Heasman J. Morpholino oligos: making sense of antisense? Dev Biol 2002; 243: 209-214.

25. Ferrero R, Torres M. Prolonged exposure of chromaffin cells to nitric oxide down-regulates the activity of soluble guanylyl cyclase and corresponding mRNA and protein levels. BMC Biochem 2002; 3: 26

26. Stasch JP, Schmidt PM, Nedvetsky PI, Nedvetskaya TY, Kumar AHS, Meurer S et al. Targeting the heme-oxidized nitric oxide receptor for selective vasodilatation of diseased blood vessels. J Clin Invest 2006; 116: 2552-2561.

27. Bidmon HJ, Starbatty J, Gorg B, Zilles K, Behrends S. Cerebral expression of the alpha2subunit of soluble guanylyl cyclase is linked to cerebral maturation and sensory pathway refinement during postnatal development. Neurochem Int 2004; 45: 821-832.

28. Ferreira $A$, Rapoport $M$. The synapsins: beyond the regulation of neurotransmitter release. Cell Mol Life Sci 2002; 59: 589-595

29. Bergsman JB, Krueger SR, Fitzsimonds RM. Automated criteria-based selection and analysis of fluorescent synaptic puncta. J Neurosci Methods 2006; 152: 32-39. 
30. Bellingham M, Evans TJ. The alpha2beta1 isoform of guanylyl cyclase mediates plasma membrane localized nitric oxide signalling. Cell Signal 2007; 19: 2183-2193.

31. da Silva JS, Dotti CG. Breaking the neuronal sphere: regulation of the actin cytoskeleton in neuritogenesis. Nat Rev Neurosci 2002; 3: 694-704.

32. Coggins PJ, Zwiers $\mathrm{H}$. Evidence for a single protein kinase $\mathrm{C}$-mediated phosphorylation site in rat brain protein B-50. J Neurochem 1989; 53: 1895-1901.

33. Chen TJ, Huang CW, Wang DC, Chen SS. Co-induction of growth-associated protein GAP-43 and neuronal nitric oxide synthase in the cochlear nucleus following cochleotomy. Exp Brain Res 2004; 158: 151-162.

34. McNamara RK, Routtenberg A. NMDA receptor blockade prevents kainate induction of protein F1/GAP-43 mRNA in hippocampal granule cells and subsequent mossy fiber sprouting in the rat. Brain Res Mol Brain Res 1995; 33: 22-28.

35. Garthwaite J, Boulton CL. Nitric oxide signaling in the central nervous system. Annu Rev Physiol 1995; 57: 683-706.

36. Grabczyk E, Zuber MX, Federoff HJ, Ng SC, Pack A, Fishman MC. Cloning and characterization of the rat gene encoding GAP-43. Eur J Neurosci 1990; 2 : 822-827.
37. Perrone-Bizzozero NI, Cansino VV, Kohn DT. Posttranscriptional regulation of GAP-43 gene expression in $\mathrm{PC} 12$ cells through protein kinase C-dependent stabilization of the mRNA. J Cell Biol 1993; 120: 1263-1270.

38. Boran MS, Garcia A. The cyclic GMP-protein kinase G pathway regulates cytoskeleton dynamics and motility in astrocytes. J Neurochem 2007; 102: 216-230.

39. Sauzeau V, Rolli-Derkinderen M, Marionneau C, Loirand G, Pacaud P. RhoA expression is controlled by nitric oxide through cGMP-dependent protein kinase activation. $\mathrm{J}$ Biol $\mathrm{Chem}$ 2003; 278: 9472-9480.

40. Wang H-G, Lu F-M, Jin I, Udo H, Kandel ER, de Vente J et al. Presynaptic and postsynaptic roles of NO, cGK and RhoA in long-lasting potentiation and aggregation of synaptic proteins. Neuron 2005; 48: 389-403.

41. Baltrons MA, Pifarré P, Berciano MT, Lafarga M, García A. LPS-induced down-regulation of NO-sensitive guanylyl cyclase in astrocytes occurs by proteasomal degradation in clastosomes. Mol Cell Neurosci 2008; 37: 494-506.

42. Appel F, Holm J, Conscience JF, Schachner M. Several extracellular domains of the neural cell adhesion molecule L1 are involved in neurite outgrowth and cell body adhesion J Neurosci 1993; 13: 4764-4775. 